\title{
Performance of Toria (Brassica campestris L.) Varieties under Namsai Conditions
}

\author{
Taba Nem ${ }^{1}$, Pranamika Sharma ${ }^{2 *}$, V.S. Devadas ${ }^{3}$, \\ G. N. Hazarika ${ }^{1}$ and Sheelawati Monlai ${ }^{1}$
}

\begin{abstract}
${ }^{1}$ Faculty of Agriculture Sciences, Arunachal University of Studies, Namsai, India
${ }^{2}$ SCS College of Agriculture, Assam Agricultural University, Rangamati, Dhubri, India

${ }^{3}$ College of Horticulture, Central Agricultural University, Thenzawl, Mizoram, India
\end{abstract}

*Corresponding author

\section{A B S T R A C T}

\section{Keywords}

Toria varieties, Seed yield

\section{Article Info}

Accepted:

17 September 2020

Available Online:

10 October 2020
Investigations were conducted to study the performance of different varieties of toria under Namsai conditions of Arunachal Pradesh at the Agricultural Research Farm of Arunachal University of Studies. Six varieties (TS-67, M-27, TS-36, TS-38, TS-46 and Jeuti) were evaluated in replicated randomized block design with four replications during November 2018 to February 2019. Observations recorded on growth and yield parameters indicated significant difference among the varieties. Maximum plant height was observed in TS-36 $(108.05 \mathrm{~cm})$ and minimum in M-27 $(99.41 \mathrm{~cm})$. Primary branches per plant was maximum in TS-36 (4.14) followed by TS-46 (3.03) and minimum in TS-67 (2.15). Maximum days to $50 \%$ flowering were observed in TS-38 (36.10), which was found to be at par with M27 (37.35), and TS-36 (38.03). It was further observed that the variety TS-67 (42.96) took longest duration for 50\% flowering, and it was at par with TS-46 (40.00). Minimum days to taken to days to maturity was recorded in TS-38 (82.13) at par with M-27 (83.28). Maximum crop duration was record in TS -67 (95.61) and was at par with Jeuti (94.55). Considering the growth and yield characters observed, the variety TS-36 (526.25 $\mathrm{g} \mathrm{plot}^{-1}$ ) was found promising and can be recommended for Namsai region.

\section{Introduction}

Rapeseed and mustard holds key place among the different oilseed crops of Indian agriculture. Toria (Brassica campestris L.) is an important short duration oilseed crop of Arunachal Pradesh cultivated during kharif season after harvest of paddy but the productivity is very poor $(520 \mathrm{~kg} / \mathrm{ha})$ which is much below the nation at average of 1176 kg/ha (Pati and Mahapatra, 2015). Under these circumstances, a trial was conducted to identify the best toria variety suited for cultivation in Namsai region of Arunachal Pradesh.

\section{Materials and Methods}

Six varieties of toria viz-, TS-67, M-27, TS36 , TS-38, TS-46, and Jeuti were evaluated in 
a randomized block design with four replications in Rabi season (Nov 2018 to Feb 2019) at the Agriculture Research Farm of Arunachal University of Studies, Namsai. The crop was sown during $2^{\text {nd }}$ week of November 2018 and harvesting was done in $3^{\text {rd }}$ week of February 2019. Plot size was 3.6 sq m. Three numbers of irrigation were given during seeding, flower initiation and siliquae development stages. Observations on growth and yield parameters were recorded at 90 days after sowing and on harvesting of the crop. The results were analysed using standard statistical procedures of ANOVA.

\section{Results and Discussion}

Data recorded were analysed and the results are furnished in table 1 . It is seen that the varieties varied significantly for all the growth and yield parameters studied. The variety TS-36 had the tallest plants (108.05 $\mathrm{cm})$ and maximum number of primary branches plant $^{-1}$ (4.14). The earliest variety for $50 \%$ flowering (36.10 days) with shortest duration to crop maturity was TS-38 (82.13 days) as compared to other treatments.

Analysis of the data indicated that TS-36 recorded the maximum yield attributing characters like numbers of siliquae plant $^{-}$ ${ }^{1}(304.55)$, number of seeds per siliqua $^{-1}$ (19.30) and seed yield plant $^{-1}(17.17 \mathrm{~g})$. Maximum 1000 seed weight $(5.41 \mathrm{~g})$ was recorded in variety TS-46. Similar varietal variations were reported by Munda et al., (2011), and Kumari et al., (2012) also.

Table.1 Mean growth and yield parameters of toria varieties

\begin{tabular}{|c|c|c|c|c|c|c|c|c|c|c|}
\hline Varieties & $\begin{array}{c}\text { Plant } \\
\text { height } \\
\text { (cm) }\end{array}$ & $\begin{array}{c}\text { Number } \\
\text { of } \\
\text { primary } \\
\text { branches }\end{array}$ & $\begin{array}{c}\text { Days to } \\
50 \% \\
\text { flowering }\end{array}$ & $\begin{array}{l}\text { Days to } \\
\text { maturity }\end{array}$ & $\begin{array}{l}\text { No. of } \\
\text { siliquae } \\
\text { per } \\
\text { plant }\end{array}$ & $\begin{array}{c}\text { No. of } \\
\text { seeds } \\
\text { per } \\
\text { siliqua }\end{array}$ & $\begin{array}{c}1000 \\
\text { seed } \\
\text { weight } \\
\text { (g) }\end{array}$ & $\begin{array}{c}\text { Seeds } \\
\text { yield } \\
\text { per } \\
\text { plant }\end{array}$ & $\begin{array}{c}\text { Seeds } \\
\text { yield } \\
\text { per } \\
\text { plot }\end{array}$ & $\begin{array}{l}\text { Average } \\
\text { seed } \\
\text { yield q } \\
\text { / ha }\end{array}$ \\
\hline TS-67 & 103.04 & 2.15 & 42.96 & 95.61 & 241.10 & 17.88 & 4.74 & 14.56 & 295.50 & 8.21 \\
\hline M-27 & 99.41 & 2.18 & 37.35 & 83.28 & 230.75 & 15.40 & 3.56 & 14.37 & 405.75 & 11.27 \\
\hline TS-36 & 108.05 & 4.14 & 38.03 & 92.53 & 304.55 & 19.30 & 3.94 & 17.17 & 526.25 & 14.62 \\
\hline TS-38 & 106.09 & 2.50 & 36.10 & 82.13 & 235.25 & 17.50 & 3.34 & 14.60 & 431.75 & 11.10 \\
\hline TS-46 & 107.01 & 3.03 & 40.00 & 90.25 & 294.00 & 18.35 & 5.41 & 16.10 & 433.25 & 12.34 \\
\hline Jeuti & 101.53 & 2.26 & 39.59 & 94.55 & 124.55 & 14.35 & 5.38 & 14.25 & 360.75 & 10.21 \\
\hline $\mathrm{CD}(\mathrm{P}=\mathbf{0 . 0 5})$ & 0.5 & 0.45 & 2.09 & 0.50 & 1.43 & 0.28 & 0.27 & 0.10 & 0.34 & 0.50 \\
\hline S.EM \pm & 0.24 & 0.15 & 0.69 & 0.60 & 0.48 & 0.32 & 0.09 & 0.6 & 0.11 & 0.60 \\
\hline
\end{tabular}

The variety TS-36 produced the maximum seed yield of (526.25 $\mathrm{g} \mathrm{plot}^{-1)}$ which is $23.8 \%$ higher than that of TS -67 (295.50g plot $\left.^{-1}\right)$. Varieties TS- 36 was characterized by higher number of siliquae per plant and seeds per siliqua. The investigations revealed that the variety TS-36 produced the highest yield (526.25 g). Varieties TS- 46 (433.25 g), TS38 (431.75 g), M-27 (405.75 g) were at par with each other. Jeuti (360.75 g), and TS-67 (295.50) had comparatively low yield. These varieties showed that higher number of siliquae per plant and number of seeds per siliqua. Growth parameters showed that these varieties were dwarf and semi-dwarf in plant height with comparatively higher number of branches per plant. The studies with seed yield verses yield attributing characters also indicating similar trend. These results are in agreement with Adak et al., (2011) and Patel (2013). 
In conclusion the investigations revealed that the variety TS-36 produced the highest yield $(526.25 \mathrm{~g})$ and is found suited for Namsai conditions. In general, varieties TS-36, TS-46 , RS-38 were also found to be promising.

\section{Acknowledgement}

The authors are thankful to the Arunachal University of Studies, Namsai for providing the facilities required for the study.

\section{References}

Adak, T; Bhaskar, N. and Chakravarty, N.V.K. (2011).Response of Brassica to microenvironment modification under semi-arid agro ecosystem. Indian Journal of Agricultural Sciences, 81 (8): 744-50.

Kumari A, Singh, R P and Yeshpal 2012.Productivity, nutrient uptake and economics of mustard hybrid under different planting time and row spacing. Indian Journal of Agronomy, 57(1): 6167.

Munda, G.C, Islam Mokiduland Nath,L.K. (2011) Integrated nutrient management approach for enhancing productivity and economics of maize (Zea Mays L.) - toria (Brassica campestris L.) cropping system. Agricultural Science Digest; 31(3):188-192.

Patel, N. (2013). Effect of sowing dates and varieties on growth, development and yield of Indian mustard under irrigated conditions. M.Sc. (Ag.) Thesis, JNKVV, Jabalpur. p128.

Pati, P. and Mahapatra, P.K. 2015.Yield performance and nutrient uptake of Indian mustard (Brassica juncea L) as influenced by integrated nutrient management. Journal Crop and Weed.11 (1):58-61.

\section{How to cite this article:}

Taba Nem, Pranamika Sharma, V. S. Devadas, G. N. Hazarika and Sheelawati Monlai. 2020. Performance of Toria (Brassica campestris L.) Varieties under Namsai Conditions. Int.J.Curr.Microbiol.App.Sci. 9(10): 2101-2103. doi: https://doi.org/10.20546/ijcmas.2020.910.255 